\title{
PENGEMBANGAN MODUL PENGECORAN LOGAM ALUMINIUM UNTUK SISWA SEKOLAH MENENGAH KEJURUAN
}

\author{
Afiata Donny Nuryanto ${ }^{1}$, Tiwan ${ }^{2}$ \\ 1,2 Jurusan Pendidikan Teknik Mesin, Fakultas Teknik, Universitas Negeri Yogyakarta \\ email: afiatadonny@gmail.com
}

\begin{abstract}
The purpose of this research is to develop aluminum casting module and to determine the feasibility of its use. The methods for the development of this module is Research and Development. The feasibility data were obtained using questionnaire and documentation. Data were analyzed using quantitative descriptive analysis in the form of score numbers that are converted into percentages and categorized according to the scaling being used. The stages in producing the module are need analysis, developing the product, validation, product revision, product test, and analysis of the tests result. The results of the feasibility test according to the material expert is $76 \%$ and is in the category of "very good". From the media expert, the feasibility is $83 \%$ and is in the category of "very good". According to the teachers, the feasibility are $87 \%$ and $88 \%$, and are in category of "very good". Responses from the students resulting in a percentage of $78 \%$ and $75 \%$ and are in the "very good" category.
\end{abstract}

Keywords: module development, aluminum casting, metal casting practice

\begin{abstract}
ABSTRAK
Tujuan penelitian ini adalah mengembangkan modul pengecoran aluminium dan mengetahui hasil uji kelayakannya. Pada Pengembangan modul ini menggunakan metode Research and Development dan data uji kelayakan yang diperoleh menggunakan angket dan dokumentasi. Data yang diperoleh dianalisis menggunakan analisis deskriptif kuantitatif dalam bentuk skor (angka) yang diubah ke dalam bentuk persentase dan dikategorikan sesuai dengan skala penilaian yang digunakan. Modul pengecoran logam aluminium dihasilkan dengan tahap-tahap: analisis kebutuhan, pembuatan produk, validasi, revisi produk, uji coba produk , dan analisis hasil uji coba produk. Hasil uji kelayakan modul pengecoran logam aluminium menurut ahli materi memperoleh persentase sebesar $76 \%$ termasuk dalam kategori sangat baik. Menurut ahli media modul pengecoran aluminium memperoleh persentase $83 \%$ termasuk dalam kategori sangat baik. Menurut guru pengampu memperoleh persentase sebesar $87 \%$ dan $88 \%$ termasuk dalam kategori sangat baik, dan hasil uji coba produk atau uji respons siswa terhadap modul pengecoran aluminium memperoleh persentase sebesar $78 \%$ dan $75 \%$ termasuk dalam kategori sangat baik.
\end{abstract}

Kata kunci: pengembangan modul, pengecoran aluminium, praktik pengecoran logam

\section{PENDAHULUAN}

Pengecoran logam merupakan salah satu kompetensi keahlian yang tidak asing lagi dan harus dikuasai oleh lulusan Sekolah Menengah Kejuruan (SMK). Hal ini berdasarkan Surat Keputusan Dirjen Pendidikan Menengah Kementerian Pendidikan dan Kebudayaan nomor: 4678/D/KEP/MK/2016 tanggal 2 september 2016 tentang Spektrum Keahlian Pendidikan Menengah Kejuruan yang menyatakan bahwa teknik pengecoran logam merupakan salah satu kompetensi keahlian yang harus dimiliki oleh lulusan Program Studi Keahlian Teknik Mesin. Hal ini direspon sangat baik oleh SMK Muhammadiyah 1 Salam dengan adanya kompetensi ini pada kurikulum 2013 pada silabus mata pelajaran teknologi mekanik yang terdapat dalam Program Studi Teknik Pemesinan pada kompetensi dasar 3.7 yaitu menerapkan pengerjaan logam dan kompetensi dasar 4.9 yaitu melaksanakan teknik pengerjaan logam. 
Kadarisman Tejo Yuwono \& Suprapto (2011: 3) menjelaskan bahwa pembelajaran berfungsi membawa peserta didik dari tidak tahu menjadi tahu. Sehingga peran pengajar sangat penting untuk membawa siswa menjadi termotivasi untuk mengikuti pembelajaran. Bambang Setiyo Hari Purwoko (2008:5) menyatakan bahwa selain pengajar harus profesional, diperlukan juga biaya dan infrastruktur pendidikan yang memadai. Apabila pendidikan diselenggarakan kurang memperhatikan persyaratan yang ditetapkan, maka akan muncul kondisi negatif, yang berdampak pada proses pembelajaran menjadi tidak berkualitas, dan sasaran pembelajaran tidak dapat dicapai. Selain itu sesuai dengan Permendiknas no.23 tahun 2006 tentang siswa SMK menguasai kompetensi program keahlian yang menjadi semakin menguatkan peran pengajar dalam pembelajaran.

Namun pada kenyataannya, sebagian besar SMK memberikan keahlian pengecoran logam sebatas teori. Hal terlihat pada sarana yang kurang memadai. Sehingga lulusan SMK menjadi kurang menguasai keterampilan pengecoran logam yang sangat berguna menambah ketrampilan siswa agar lebih siap untuk menghadapi dunia kerja, baik di industri maupun berwirausaha.

Salah satu mata pelajaran pada kurikulum SMK Progam Keahlian Teknik Mesin yang mempunyai mata pelajaran teknologi mekanika yang berisi tentang pengecoran logam. Namun kompetensi keahlian pengecoran logam sebatas teori saja. Sehingga munculah salah satu solusi membuat sarana praktik yaitu tungku pelebur alumunium sederhana dan mudah dalam mengoperasikannya ataupun perawatannya.

Kesulitan lainnya yaitu terbatasnya waktu belajar mengajar di kelas terkadang menghalangi para guru dalam memberikan semua materi pelajaran kepada siswanya. Hal ini menjadi masalah tersendiri untuk para guru dalam menyampaikan secara detail mata pelajaran tersebut. Kesulitan ini juga dikeluhkan oleh siswa yang terkadang materi yang membutuhkan penjelasan dan praktik dalam waktu lama justru harus dipadat pada waktu yang singkat.

Berawal dari masalah inilah maka salah satu solusinya yaitu membuat media pembelajaran untuk pengecoran logam berupa modul pengecoran logam alumunium sebagai media pendukung praktik pengecoran. Hasil observasi awal yang dilaksanakan di di SMK Muhammadiyah 1 Salam, Magelang khususnya tentang pengembangan modul, ditemukan bahwa masih minim apabila dilihat dari segi konten maupun standarisasi. Dengan pembuatan media ini masalah yang dapat diselesaikan yaitu seperti: proses pembelajaran menjadi optimal, kesulitan siswa dalam pemahaman teknik pengecoran menjadi mudah dengan adanya kesesuaian teori dan praktik, pengetahuan guru dan siswa semakin luas dan aplikatif

Berdasarkan latar belakang yang telah dipaparkan diatas, maka dapat dilakukan pengembangan modul pengecoran logam alumunium sebagai media pendukung pada praktik pengecoran logam alumunium di SMK Muhammadiyah 1 Salam.

\section{METODE}

Model pengembangan pada penelitian ini menggunakan jenis penelitian Research and Development (R\&D). Langkah-langkah yang ditempuh dalam pengembangan modul pengecoran aluminium ini menggunakan langkah-langkah pengembangan yang dikemukakan oleh Sugiyono (2010:409). Pada pengembangan modul pengecoran logam alumunium ada enam tahapan dalam proses pengembangan produk ini, yaitu: analisis kebutuhan, pembuatan produk, validasi, revisi produk, uji coba produk dan analisis hasil uji coba produk

Subyek penelitian adalah guru mata pelajaran Teknologi Mekanik siswa kelas X TMP-A dan TMP-B jurusan Teknik Pemesinan SMK Muhammadiyah 1 Salam. Objek penelitian berupa modul pengecoran logam aluminium. 
Pengembangan modul pengecoran logam aluminium ini meliputi pengembangan materi dan pengembangan media. Hasil yang diperoleh dari pengembangan materi berupa bahan materi untuk pembelajaran pengecoran aluminium. Penyusunan materi dalam modul ini dilakukan dengan memanfaatkan buku teks, handout, modul pembelajaran dan informasi yang ada tersedia online, kemudian disusun kembali dengan gaya bahasa yang sesuai dan selanjutnya dikemas menjadi modul yang memenuhi karateristik modul yang baik. Prosedur pengembangan yang ditempuh untuk membuat modul pengecoran logam di SMK Muhammadiyah 1 Salam, yaitu: analisis kebutuhan, pembuatan produk, validasi, revisi produk, uji coba produk, dan analisis hasil uji coba produk.

Data penelitian ini berupa nilai hasil uji kelayakan modul dari validasi ahli dan uji respon siswa. Teknik atau cara pengumpulan data menggunakan instrumen angket dan dokumentasi, dengan tujuan untuk menentukan kelayakan modul pengecoran aluminium, angket digunakan saat uji ahli media, uji ahli materi, uji guru pengampu dan uji respon siswa. Teknik pengumpulan data dengan dokumentasi digunakan saat uji coba modul. Angket yang digunakan adalah angket tertutup untuk menilai kelayakan modul yang dikembangkan.

Teknik analisis data yang dilakukan menggunakan teknik analisis deskriptif kuantitatif, yaitu dengan menganalisis data kuantitatif yang diperoleh dari angket/kuisioner uji ahli dan uji respon siswa. Data kuantitatif yang berwujud angka-angka hasil perhitungan atau pengukuran dapat diproses dengan cara dijumlah, dibandingkan dengan jumlah yang diharapkan dan diperoleh persentase, dengan skala sebagai berikut: sangat baik (76\%-100\%), baik (56\%-75\%), cukup (40\%$55 \%)$, kurang baik (0-39\%). Skala persentase tersebut digunakan untuk menentukan nilai kelayakan produk berupa modul pengecoran aluminium yang dihasilkan.

\section{HASIL DAN PEMBAHASAN}

Validasi modul pengecoran aluminium oleh ahli materi menggunakan angket yang tertutup. Untuk hasil uji kelayakan modul dari segi materi ini ditampilkan pada Tabel 1.

Tabel 1. Uji Kelayakan Ahli Materi

\begin{tabular}{|c|c|c|c|c|}
\hline Aspek & $\begin{array}{c}\text { Skor } \\
\text { Observasi }\end{array}$ & $\begin{array}{c}\text { Skor } \\
\text { diharapkan }\end{array}$ & $\%$ & Kategori \\
\hline $\begin{array}{l}\text { Kelayakan } \\
\text { Isi }\end{array}$ & 54 & 68 & 79 & $\begin{array}{l}\text { Sangat } \\
\text { Baik }\end{array}$ \\
\hline $\begin{array}{l}\text { Kelayakan } \\
\text { Penyajian }\end{array}$ & 36 & 48 & 75 & Baik \\
\hline $\begin{array}{c}\text { Penilaian } \\
\text { bahasa }\end{array}$ & 37 & 52 & 71 & Baik \\
\hline $\begin{array}{c}\text { Kelayakan } \\
\text { modul }\end{array}$ & 3 & 4 & 75 & Baik \\
\hline Jumlah & 133 & 176 & 76 & Layak \\
\hline
\end{tabular}

Pada Tabel 1 dapat diuraikan yaitu: pada aspek kelayakan isi materi memperoleh persentase sebesar $79 \%$ termasuk dalam kategori sangat baik. Namun ada beberapa hal yang perlu diperbaiki yaitu seperti kejelasan isi materi dan penyusunan isi materi. Pengembangan lebih lanjut dapat dilakukan dengan mengembangkan materi lebih jelas dan penyampaian lebih komunikatif. Aspek kelayakan penyajian memperoleh persentase sebesar $75 \%$ termasuk dalam kategori baik. Namun ada beberapa evaluasi seperti kesesuaian gambar dengan isi materi dan penyajian kalimat perlu disempurnakan. Pengembangan lebih lanjut yaitu seperti isi materi yang sudah ada disusun lebih menarik serta variatif. Aspek penilaian bahasa memperoleh persentasae $71 \%$ termasuk dalam kategori baik. Namun ada beberapa perbaikan yaitu struktur kalimat disesuaikan dan penyajian istilah-istilah yang digunakan. Pengembangan lebih lanjut yaitu dengan menempatkan kalimat yang sesuai dengan lebih efektif. Aspek kelayakan modul memperoleh persentase sebesar $75 \%$ dan termasuk dalam kategori baik. Beberapa perbaikan serperti kejelasan materi, penyajian konten isi dan penggunaan kalimat. Pengembangan lebih lanjut dengan menambah keakuratan materi dan 
penyajian isi lebih terkonsep. Nilai keseluruhan validasi oleh ahli materi, memperoleh persentase sebesar $76 \%$ dan termasuk dalam kategori layak digunakan sebagai media pembelajaran. Beberapa perbaikan seperti isi materi, penataan tabel, kesesuaian gambar dengan keterangan. Pengembangan untuk berikutnya dapat dilakukan dengan mempertajam isi materi yang lebih luas, penyajian isi materi ditampilkan lebih variatif.

Validasi modul pengecoran aluminium dari segi media menggunakan angket tertutup. Hasil uji kelayakan ditampilkan pada Tabel 2.

Tabel 2. Uji Kelayakan Ahli Media

\begin{tabular}{ccccc}
\hline Aspek & $\begin{array}{c}\text { Skor } \\
\text { Observasi }\end{array}$ & $\begin{array}{c}\text { Skor } \\
\text { diharapkan }\end{array}$ & $\%$ & Kategori \\
\hline $\begin{array}{c}\text { Kelayakan } \\
\text { Penyajian }\end{array}$ & 27 & 32 & 84 & $\begin{array}{c}\text { Sangat } \\
\text { baik }\end{array}$ \\
$\begin{array}{c}\text { Kelayakan } \\
\text { Bahasa }\end{array}$ & 13 & 16 & 81 & $\begin{array}{c}\text { Sangat } \\
\text { Baik }\end{array}$ \\
$\begin{array}{c}\text { Kelayakan } \\
\text { Kegrafikan } \\
\text { Kelayakan } \\
\text { Media }\end{array}$ & 56 & 68 & 82 & $\begin{array}{c}\text { Sangat } \\
\text { baik } \\
\text { Baik }\end{array}$ \\
\hline Jumlah & 99 & 120 & 83 & Layak \\
\hline
\end{tabular}

Pada Tabel 2 dapat diuraikan yaitu: pada aspek kelayakan penyajian pada modul pengecoran aluminium memperoleh persentase sebesar $84 \%$ dan termasuk dalam kategori sangat baik. Namun terdapat beberapa perbaikan seperti keruntutan dan keterpaduan kalimat diperjelas agar mudah dibaca. Pengembangan kedepan dapat dilakukan dengan menyajikan kalimat yang lebih komunikatif, mengembangkan keruntutan antar paragraf. Aspek kelayakan bahasa pada modul pengecoran aluminium memperoleh persentase sebesar $81 \%$ dan termasuk dalam kategori sangat baik. Beberapa hal yang perlu diperbaiki seperti penyajian tanda baca, penyusunan kalimat pada paragraf. Pengembangan aspek kelayakan bahasa seperti penyajian kalimat yang lebih efektif, pemilihan bahasa yang lebih komunikatif. Aspek berikutnya yaitu aspek Kelayakan kegrafikan yaitu memperoleh persentase sebesar $82 \%$ dan termasuk dalam kategori sangat baik. beberapa hal yang perlu diperbaiki meliputi ukuran penyajian gambar, kalimat pada keterangan gambar. Pengembangan aspek kelayakan kegrafikan yaitu seperti penyajian konten modul dikembangkan lebih variatif, penataan tabel lebih disesuaikan. Aspek kelayakan modul mendapat persentase sebesar $75 \%$ dan termasuk dalam kategori baik. Beberapa perbaikan pada aspek media seperti penyajian modul perlu disempurnakan. Pengembangan berikutnya dapat dilakukan dengan menyajikan konten yang lebih mendukung, pemilihan kalimat yang lebih komunikatif.

Rerata validasi dari segi media, memperoleh persentase sebesar $83 \%$ dan termasuk dalam kategori layak digunakan. Namun ada beberapa perbaikan seperti penyajian modul dan penggunaan bahasa pada modul. Pengembangan lebih lanjut yaitu dengan menampilkan konten yang lebih menarik, tampilan disajikan lebih beda, bahasa lebih komunikatif.

Validasi modul pengecoran aluminium oleh guru pengampu menggunakan angket tertutup. Hasil uji guru pengampu ditampilkan pada Tabel 3.

\section{Tabel 3. Uji Guru Pengampu}

\begin{tabular}{|c|c|c|c|c|}
\hline Aspek & $\begin{array}{l}\text { Skor } \\
\text { Observasi }\end{array}$ & $\begin{array}{l}\text { Skor } \\
\text { diharapkan }\end{array}$ & $(\%)$ & Kategori \\
\hline $\begin{array}{l}\text { Konsep } \\
\text { Media }\end{array}$ & 36 & 40 & 90 & $\begin{array}{l}\text { Sangat } \\
\text { Baik }\end{array}$ \\
\hline $\begin{array}{l}\text { Tampila } \\
\text { Media }\end{array}$ & 64 & 72 & 88 & $\begin{array}{c}\text { Sangat } \\
\text { Baik }\end{array}$ \\
\hline $\begin{array}{l}\text { Kualitas } \\
\text { Materi }\end{array}$ & 33 & 40 & 83 & $\begin{array}{c}\text { Sangat } \\
\text { Baik }\end{array}$ \\
\hline $\begin{array}{l}\text { Isi } \\
\text { Materi }\end{array}$ & 75 & 88 & 85 & $\begin{array}{c}\text { Sangat } \\
\text { Baik }\end{array}$ \\
\hline Strategi & 23 & 24 & 95 & $\begin{array}{c}\text { Sangat } \\
\text { Baik }\end{array}$ \\
\hline & Rata-rata & & 88 & Layak \\
\hline
\end{tabular}

Pada Tabel 3 dapat diuraikan yaitu: pada aspek konsep media memperoleh persentase sebesar $90 \%$ dan termasuk kategori sangat baik. Pengembangan lebih lanjutkan seperti tampilan konten modul lebih divariatif lagi, kualitas 
materi lebih ditingkatkan lagi, isi materi lebih diakuratkan lagi.

Pada aspek tampilan media memperoleh persentase sebesar $88 \%$ dan termasuk kategori sangat baik. Pengembangan lebih lanjut dapat dilakukan dengan mengkonsep tampilan lebih menarik, kualitas tampilan materi lebih diakuratkan, isi tampilan materi lebih dikembangkan, membuat tampilan strategi pembelajaran lebih mudah untuk digunakan dalam pembelajaran.

Kemudian aspek pemilihan kualitas materi memperoleh persentase sebesar $83 \%$ dan termasuk dalam kategori sangat baik. Pengembangan lebih lanjut dapat dilakukan dengan konsep materi yang lebih runtut, dan tampilan isi materi lebih runtut. Aspek isi materi memperoleh persentase sebesar $85 \%$ dan termasuk dalam kategori sangat baik. Pengembangan lebih lanjut dapat dilakukan dengan lebih memperjelas konsep isi materi, tampilan isi materi lebih menarik. Aspek terakhir yaitu strategi pembelajaran yang memperoleh persentase sebesar $95 \%$ dan termasuk dalam kategori sangat baik. Nilai keseluruhan uji guru pengampu, memperoleh persentase sebesar $87 \%$ dan termasuk kategori sangat baik sehingga layak digunakan. Pengembangan lebih lanjut dapat dilakukan dengan lebih memperjelas konsep materi, tampilan media lebih menarik dan isi materi lebih dikembangkan.

Uji respon siswa dilakukan menggunakan angket tertutup hasil repon siswa ditampilkan pada Tabel 4. Aspek pembelajaran mendapatkan skor $79 \%$ dan termasuk dalam kategori sangat baik. Pengembangan lebih lanjut yaitu seperti isi materi pembelajaran lebih diperdalam, konsep media pembelajaran lebih diperjelas agar semakin mudah dimengerti siswa, tampilan media pembelajaran dibuat lebih menarik.
Tabel 4. Uji Respon Siswa

\begin{tabular}{|c|c|c|c|c|}
\hline Aspek & $\begin{array}{c}\text { Skor } \\
\text { Jbservasi }\end{array}$ & $\begin{array}{c}\text { Skor } \\
\text { diharapkan }\end{array}$ & $\%$ & Kategori \\
\hline Pembelajaran & 1638 & 2048 & 79 & $\begin{array}{l}\text { Sangat } \\
\text { Baik }\end{array}$ \\
\hline Isi / Materi & 797 & 1024 & 78 & $\begin{array}{c}\text { Sangat } \\
\text { Baik }\end{array}$ \\
\hline $\begin{array}{l}\text { Konsep } \\
\text { Media }\end{array}$ & 797 & 1024 & 78 & $\begin{array}{c}\text { Sangat } \\
\text { Baik }\end{array}$ \\
\hline $\begin{array}{l}\text { Tampilan } \\
\text { Media }\end{array}$ & 769 & 1024 & 75 & Baik \\
\hline \multicolumn{2}{|c|}{ Rata - rata } & 77 & Lay & \\
\hline
\end{tabular}

Aspek isi materi mendapatkan skor $78 \%$ dan termasuk dalam aspek sangat baik. Beberapa hal yang diperbaiki salah satunya penjelasan materi dalam perlu ditambahkan. Pengembangan aspek ini dapat dilakukan dengan menambah penjelasan isi materi pada setiap pembelajaran agar siswa semakin mudah menerima isi materi, memperjelas isi materi pada alur pembelajaran agar muatan isi pembelajaran lebih spesifik dan mudah dipahami siswa, tampilan isi materi dibuat lebih variatif agar dapat menarik minat belajar siswa Aspek konsep media mendapatkan skor sebesar $78 \%$ dan masuk pada kriteria sangat baik. Pengembangan aspek ini yaitu dengan memperjelas alur pembelajaran, konsep penempatan isi materi pada setiap kegiatan pembelajaran lebih disesuaikan dengan tujuan pembelajaran, konsep tampilan media didesain lebih variatif. Aspek tampilan media mendapatkan skor $78 \%$ dan masuk dalam kriteria sangat baik. Perbaikan aspek ini meliputi ilustrasi gambar, warna huruf, istilah dan simbol agar memudahkan siswa dalam melakukan kegiatan pembelajaran. Pengembangan lebih lanjut dapat dilakukan dengan tampilan pembelajaran dibuat lebih menarik, tampilan isi dibuat lebih variatif, konsep tampilan diperjelas. Rerata presentase untuk keempat aspek adalah sebesar $77 \%$. Sehingga modul pengecoran logam dapat dikatakan layak digunakan dengan. 


\section{SIMPULAN}

Berdasarkan hasil penelitian dan pembahasan diperoleh kesimpulan, yaitu: (1) Modul pengecoran aluminium pada mata pelajaran teknologi mekanik di SMK Muhammadiyah 1 Salam Jurusan Teknik Mesin telah dihasilkan dengan tahap sesuai prosedur pengembangan, yaitu: analisis, pembuatan produk, validasi, revisi produk, uji coba produk. Dan analisi hasil uji coba produk. (2) Hasil uji kelayakan modul pengecoran aluminium adalah sangat layak untuk digunakan, hal ini dapat terlihat dari validasi uji ahli materi, uji ahli media, uji guru pengampu dan uji respon siswa menunjukan bahwa modul pengecoran aluminium layak digunakan sebagai panduan praktik pengecoran aluminium.

\section{DAFTAR RUJUKAN}

Direktur Jenderal Pendidikan Menengah. (2016). Spektrum Keahlian Pendidikan Menengah Kejuruan. Diakses tanggal 14 agustus 2017, Jam 20.55 WIB dari http://luk.staff.ug m.ac.id/atur/bsnp/ Permendikb ud70-2016KDStruktur Kurik ulum-SMK-MAK.pdf.
Permendiknas. (2006). Standar Kompetensi Lulusan-Satuan Pendidikan. Diakses tanggal 7 mei 2017, Jam 20.45 WIB dari https://sites.google.com/site/pendidikante rpadu/home/permendiknas-nomor-23tahu n-2006.

Purwoko, Bambang Setyo Hari. (2008). Pengembangan Media Mesin Cnc Virtual Tu-3a Sebagai Media Pembelajaran Mata Kuliah Pemesinan Nc. Yogyakarta: Jurnal Pendidikan Teknologi Kejuruan UNY. 17(1), 1-22

Sugiyono. (2010). Metode Penelitian Pendidikan. Bandung: Alfabeta.

Suharsimi Arikunto. (1993). Prosedur Penelitian Suatu Pendekatan Praktek. Jakarta: PT. Rineka Cipta.

Tjipto Utomo. (1991). Peningkatan dan Pengembangan Pendidikan. Jakarta: Gramedia Pustaka Utama.

Kadarisman Tejo Yuwono dan Suprapto. (2011). Pengembangan Modul Praktikum Mikrokontroler (Avr) Menggunakan Perangkat Lunak Proteus Professional V7.5 Sp3 Teknik Penyusunan Instrumen Penelitian. Yogyakarta: Jurnal Pendidikan Teknologi Kejuruan UNY, 20 (1), 21-24. 